\title{
Landfast ice thickness in the Canadian Arctic Archipelago from observations and models
}

\author{
Stephen E. L. Howell ${ }^{1}$, Frédéric Laliberté ${ }^{1}$, Ron Kwok ${ }^{2}$, Chris Derksen ${ }^{1}$, and Joshua King ${ }^{1}$ \\ ${ }^{1}$ Climate Research Division, Environment and Climate Change Canada, Toronto, Canada \\ ${ }^{2}$ Jet Propulsion Laboratory, California Institute of Technology, Pasadena, California, USA \\ Correspondence to: Stephen E. L. Howell (stephen.howell@ canada.ca)
}

Received: 23 March 2016 - Published in The Cryosphere Discuss.: 30 March 2016

Revised: 15 June 2016 - Accepted: 21 June 2016 - Published: 12 July 2016

\begin{abstract}
Observed and modelled landfast ice thickness variability and trends spanning more than 5 decades within the Canadian Arctic Archipelago (CAA) are summarized. The observed sites (Cambridge Bay, Resolute, Eureka and Alert) represent some of the Arctic's longest records of landfast ice thickness. Observed end-of-winter (maximum) trends of landfast ice thickness (1957-2014) were statistically significant at Cambridge Bay $\left(-4.31 \pm 1.4 \mathrm{~cm} \mathrm{decade}^{-1}\right)$, Eureka $\quad\left(-4.65 \pm 1.7 \mathrm{~cm} \mathrm{decade}^{-1}\right)$ and Alert $\left(-4.44 \pm 1.6 \mathrm{~cm} \mathrm{decade}^{-1}\right)$ but not at Resolute. Over the 50+-year record, the ice thinned by $\sim 0.24-0.26 \mathrm{~m}$ at Cambridge Bay, Eureka and Alert with essentially negligible change at Resolute. Although statistically significant warming in spring and fall was present at all sites, only low correlations between temperature and maximum ice thickness were present; snow depth was found to be more strongly associated with the negative ice thickness trends. Comparison with multi-model simulations from Coupled Model Intercomparison project phase 5 (CMIP5), Ocean Reanalysis Intercomparison (ORA-IP) and Pan-Arctic Ice-Ocean Modeling and Assimilation System (PIOMAS) show that although a subset of current generation models have a "reasonable" climatological representation of landfast ice thickness and distribution within the CAA, trends are unrealistic and far exceed observations by up to 2 orders of magnitude. ORA-IP models were found to have positive correlations between temperature and ice thickness over the CAA, a feature that is inconsistent with both observations and coupled models from CMIP5.
\end{abstract}

\section{Introduction}

The World Meteorological Organization (WMO, 1970) defines landfast sea ice as "sea ice which remains fast along the coast, where it is attached to the shore, to an ice wall, to an ice front, or over shoals, or between grounded icebergs". In the Arctic, this ice typically extends to the $20-30 \mathrm{~m}$ isobaths (Mahoney et al., 2007, 2014). It melts each summer and re-forms in the fall but there are regions along the northern coast of the Canadian Arctic Archipelago (CAA) where multi-year landfast ice (also termed an "ice plug") is present. The two most prominent regions of multi-year landfast sea ice in the CAA are located in Nansen Sound and Sverdrup Channel (Serson, 1972, 1974) (Fig. 1). It has been documented that ice remained intact from 1963 to 1998 in Nansen Sound and from 1978 to 1998 in Sverdrup Channel (Jeffers et al., 2001; Melling, 2002; Alt et al., 2006). The extreme warm year of 1998 disintegrated the ice in both regions and their survival during the summer melt season in recent years has occurred less frequently (Alt et al., 2006). Over the entire Arctic, landfast ice extent is declining at $7 \%$ decade $^{-1}$ since the mid-1970s (Yu et al., 2014).

Records of landfast ice thickness provide annual measures of ice growth that can also almost entirely be attributed to atmospheric forcing with negligible deep ocean influence on local ice formation. While the key forcings on landfast ice and offshore ice are different, the seasonal behaviour of landfast ice can nevertheless provide useful information for understanding the interannual variability of ice thickness in both regimes. Presently, there is no pan-Arctic network for monitoring changes in landfast ice but available measurements suggest thinning in recent years. Thickness measurements near Hopen, Svalbard, revealed thinning of landfast 


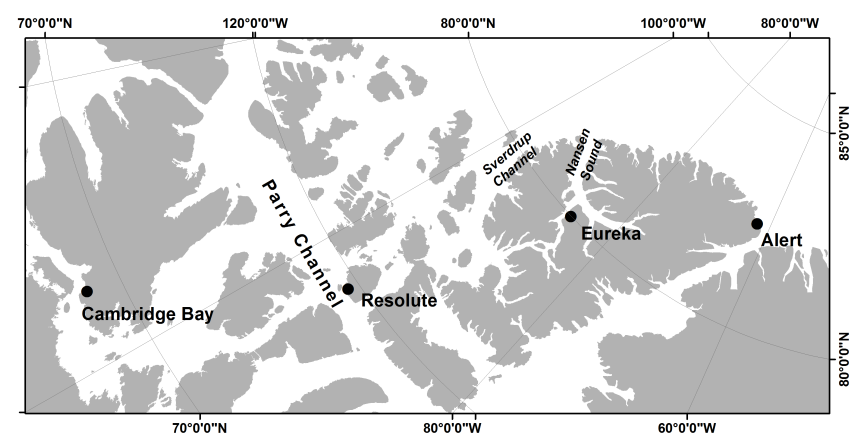

Figure 1. Map of the central Canadian Arctic Archipelago showing the location of the landfast snow and thickness observations.

ice in the Barents Sea region by $11 \mathrm{cmdecade}^{-1}$ between 1966 and 2007 (Gerland et al., 2008). From a composite time series of landfast ice thickness from 15 stations along the Siberian coast, Polyakov et al. (2010) estimate an average rate of thinning of $3.3 \mathrm{~cm} \mathrm{decade}^{-1}$ between the mid-1960s and early 2000s. Relatively recent observations by Mahoney et al. (2007) and Druckenmiller et al. (2009) found longer ice-free seasons and thinner landfast ice compared to earlier records.

At four sites in the CAA, Brown and Cote (1992) (hereinafter, BC92) provided the first examination of the interannual variability of end-of-winter (maximum) landfast ice thickness and associated snow depth over the period 19571989. Their results highlighted the insulating role of snow cover in explaining 30-60\% of the variance in maximum ice thickness. Similar results were also reported by Flato and Brown (1996) and Gough et al. (2004). In the record examined by BC92, no evidence for systematic thinning of landfast ice in the CAA was found. Landfast ice thickness records at several of these CAA sites are now over 50 years in length, which represents an addition of more than 2 decades of measurements since BC92 during a period that saw dramatic reductions in the extent and thickness of Arctic sea ice (e.g. Kwok and Rothrock, 2009; Stroeve et al., 2012).

The sparse network of long-term observations of snow and ice thickness in the Arctic (clearly exhibited by only four ongoing measurements sites operated by Environment Canada in the CAA) has made the use of models imperative to provide a broader regional scale perspective of sea ice trends in a warming climate. Given the coarse spatial resolution of global climate models, previous studies focusing on the CAA have relied on either a one-dimensional thermodynamic dynamic model (Flato and Brown, 1996; Dumas et al., 2006) or a regional three-dimensional ice-ocean coupled model (e.g. Sou and Flato, 2009). Specifically, Dumas et al. (2006) found projected maximum ice thickness decreases of $30 \mathrm{~cm}$ by $2041-2060$ and $50 \mathrm{~cm}$ by 2081-2100 and Sou and Flato (2009) reported a potential $17 \%$ decrease in overall ice thickness throughout the CAA by 2041-2060. However, in recent years some global climate models, reanalysis products and data assimilation systems have become of sufficient spatial resolution to assess potential landfast ice thickness changes within the CAA.

This analysis examines the trends of measured landfast ice thickness, snow depth and air temperature over a 50+-year period between 1957 and 2014 and compares the results with the earlier analysis by BC92. We then use this observational foundation to evaluate the representativeness of landfast ice in state-of-the-art global climate models, assimilation systems and reanalysis products.

\section{Data description}

\subsection{Observations}

Landfast ice thickness and corresponding snow depth measurement have been made regularly at many coastal stations throughout Canada since about 1950 . These data are quality controlled and archived at the Canadian Ice Service (CIS) and represent one of the few available sources of continuous ice thickness measurements in the Arctic. In general, thickness measurements are taken once per week, starting after freeze-up when the ice is safe to walk on and continuing until breakup or when the ice becomes unsafe. Complete details of this data set are provided by Brown and Cote (1992). The data set is available on the CIS web site (http://www.ec.gc.ca/glaces-ice/, see Archive followed by Ice Thickness Data). Four sites in the CAA were selected for study: Alert, Eureka, Resolute and Cambridge Bay (Fig. 1). Although there are other sites in the database, these sites are the only ones than span the same 55-year period between 1960 and 2014. The record at Mould Bay, used in BC92, terminated in the early 1990s. Together these sites cover $\sim 20^{\circ}$ in latitude (Fig. 1) adjacent to an area of thick Arctic sea ice that experienced the highest thinning in recent years (Kwok and Rothrock, 2009; Laxon et al., 2013). Values of maximum or end-of-winter ice thickness and corresponding snow depth during the ice growth season were extracted from the weekly ice and snow thickness data at the selected sites (see Supplement). As this study is concerned with annual variability in maximum ice thickness, the main period of interest extends from September to late May.

The other source of observed data used in this study was Environment Canada's monthly mean air temperature records at Alert, Eureka, Resolute and Cambridge Bay for which a complete description is provided by Vincent et al. (2012).

\subsection{Models}

The representation of CAA landfast sea ice thickness within the Coupled Model Intercomparison project phase 5 (CMIP5) is analysed using the 1850-2005 Historical experiment followed by the 2006-2099 Representative Concentration Pathway 8.5 (RCP85) experiment (Taylor et al., 2012) 
Table 1. CMIP5 models used in this study, the number of realizations with ice data and the number of realizations with sea ice transport data.

\begin{tabular}{lclc}
\hline & \# of simulations & & \# of simulations \\
\hline bcc-csm1-1 & 1 & MIROC-ESM-CHEM & 1 \\
bcc-csm1-1-m & 1 & MIROC5 & 3 \\
BNU-ESM & 1 & HadGEM2-CC & 1 \\
CanESM2 & 5 & HadGEM2-ES & 4 \\
CMCC-CESM & 1 & MPI-ESM-LR & 3 \\
CMCC-CM & 1 & MPI-ESM-MR & 1 \\
CMCC-CMS & 1 & MRI-CGCM3 & 1 \\
CNRM-CM5 & 5 & CCSM4 & 6 \\
ACCESS1.0 & 1 & NorESM1-M & 1 \\
ACCESS1.3 & 1 & NorESM1-ME & 1 \\
CSIRO-Mk3.6.0 & 10 & GFDL-CM3 & 1 \\
FIO-ESM & 1 & GFDL-ESM2G & 1 \\
EC-EARTH & 6 & GFDL-ESM2M & 1 \\
inmcm4 & 1 & CESM1(BGC) & 1 \\
FGOALS-g2 & 1 & CESM1(CAM5) & 3 \\
MIROC-ESM & 1 & CESM1(WACCM) & 3 \\
\hline
\end{tabular}

(Table 1). Monthly sea ice thickness (variable sit), sea ice concentration (variable sic), $2 \mathrm{~m}$ temperature (variable tas) and snow depth (variable snd) were used. The CMIP5 data were retrieved from the British Atmospheric Data Centre database and accessed through the Centre for Environmental Data Analysis (www.ceda.ac.uk). Ensemble r6ilp1 and r7i1p1 from model EC-EARTH were removed because of corrupted data. We obtain the multi-model mean of trends and their statistical significance at each grid point by creating the distribution of trends through a Monte Carlo simulation. We use a $t$ distribution for the interannual variability and build a noise model to account for internal variability as in Swart et al. (2015) and Laliberté et al. (2016). We obtain the multi-model mean of Pearson correlations and their statistical significance by first performing a Fisher transform and then applying the same method as for the trends. The inverse Fisher transform is applied after obtaining the multi-model mean and its significance. See the appendix for a complete description of the method.

We also investigate ice thickness values from a selection of the highest-resolution models (Storto et al., 2011; Forget et al., 2015; Haines et al., 2014; Zuo et al., 2015; Masina et al., 2015), from the Ocean Reanalysis Intercomparison (ORA-IP) (Balmaseda et al., 2015; Chevallier et al., 2016) (Table 2) and from the Pan-Arctic Ice-Ocean Modeling and Assimilation System (PIOMAS) (Zhang and Rothrock, 2003). Supporting $2 \mathrm{~m}$ temperature data were obtained from ERA-Interim (Dee et al., 2011).

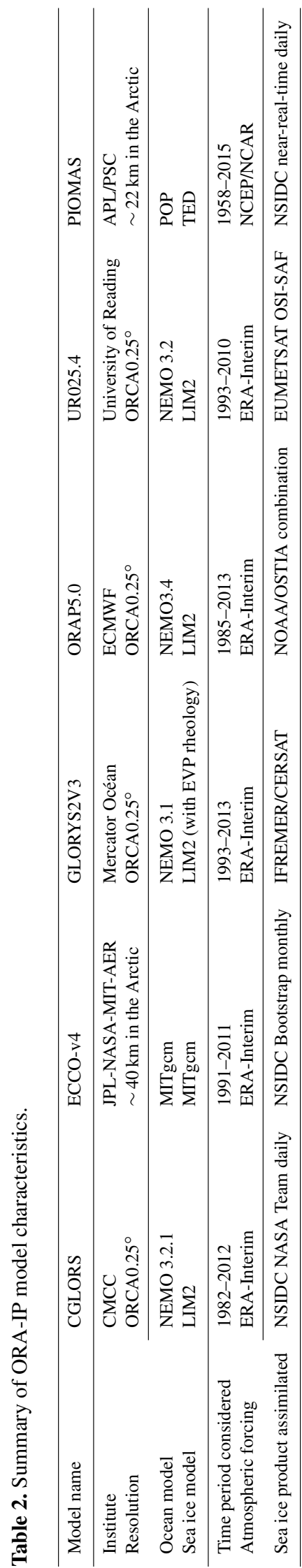

The Cryosphere, 10, 1463-1475, 2016 
Table 3. Observed maximum ice thickness, snow depth and surface air temperature at four landfast ice sites in the Canadian Arctic Archipelago. The bold text indicates statistical significance of the linear trend at $95 \%$ or greater.

\begin{tabular}{|c|c|c|c|c|}
\hline Period & $\begin{array}{r}\text { Cambridge Bay } \\
1960-2014\end{array}$ & $\begin{array}{c}\text { Resolute } \\
\text { 1957-2014 }\end{array}$ & $\begin{array}{r}\text { Eureka } \\
1957-2014\end{array}$ & $\begin{array}{c}\text { Alert } \\
1957-2014\end{array}$ \\
\hline \multicolumn{5}{|l|}{ Ice Thickness, $h_{\text {ice }}$} \\
\hline Mean of $\max h_{\text {ice }}(\mathrm{m})$ & $2.11 \pm 0.19$ & $2.02 \pm 0.19$ & $2.27 \pm 0.23$ & $1.98 \pm 0.22$ \\
\hline Trend of max $h_{\text {ice }}\left(\mathrm{cm} \mathrm{decade}^{-1}\right)$ & $-4.31 \pm 1.4$ & $-0.5 \pm 1.6$ & $-4.65 \pm 1.7$ & $-4.44 \pm 1.6$ \\
\hline Day of $\max h_{\text {ice }}$ & 24 May \pm 17 & 25 May \pm 21 & 26 May \pm 12 & 27 May \pm 16 \\
\hline Trend of day of $\max h_{\text {ice }}\left(\right.$ days decade $\left.{ }^{-1}\right)$ & $-0.87 \pm 1.5$ & $-6.2 \pm 1.5$ & $-2.0 \pm 0.1$ & $-3.0 \pm 1.2$ \\
\hline \multicolumn{5}{|l|}{ Snow depth $\left(h_{\text {snow }}\right)$} \\
\hline Mean Oct-May $h_{\text {snow }}(\mathrm{cm})$ & $8.4 \pm 4.2$ & $22.6 \pm 10$ & $17.6 \pm 5.8$ & $18.4 \pm 6.2$ \\
\hline Trend of Oct-May $h_{\text {snow }}\left(\mathrm{cm} \mathrm{decade}^{-1}\right)$ & $-0.8 \pm 0.4$ & $-0.75 \pm 0.8$ & $0.54 \pm 0.5$ & $0.26 \pm 0.5$ \\
\hline \multicolumn{5}{|l|}{ Temperature } \\
\hline Winter $(\mathrm{Dec}-\mathrm{Feb})$ mean $\left({ }^{\circ} \mathrm{C}\right)$ & $-31.3 \pm 2.0$ & $-30.8 \pm 1.9$ & $-36.0 \pm 2.0$ & $-31.2 \pm 1.6$ \\
\hline Winter $(\mathrm{Dec}-\mathrm{Feb})\left({ }^{\circ} \mathrm{Cdecade}^{-1}\right)$ & $0.59 \pm 0.2$ & $0.35 \pm 0.1$ & $0.23 \pm 0.2$ & $0.38 \pm 0.1$ \\
\hline Spring (Mar-May) mean $\left({ }^{\circ} \mathrm{C}\right)$ & $-20.0 \pm 1.8$ & $-21.1 \pm 1.8$ & $-24.9 \pm 2.0$ & $-22.8 \pm 1.8$ \\
\hline Spring (Mar-May) $\left({ }^{\circ} \mathrm{Cdecade}^{-1}\right)$ & $0.47 \pm 0.1$ & $0.57 \pm 0.1$ & $0.44 \pm 0.1$ & $0.32 \pm 0.1$ \\
\hline Summer (Jun-Aug) mean $\left({ }^{\circ} \mathrm{C}\right)$ & $5.9 \pm 1.4$ & $2.3 \pm 1.3$ & $3.9 \pm 1.2$ & $1.3 \pm 0.8$ \\
\hline Summer (Jun-Aug) $\left({ }^{\circ} \mathrm{C}\right.$ decade $\left.^{-1}\right)$ & $0.30 \pm 0.1$ & $0.17 \pm 0.2$ & $0.21 \pm 0.1$ & $0.1 \pm 0.1$ \\
\hline Fall (Sep-Nov) mean $\left({ }^{\circ} \mathrm{C}\right)$ & $-11.1 \pm 2.0$ & $-13.8 \pm 2.0$ & $-19.6 \pm 2.2$ & $-18.0 \pm 1.7$ \\
\hline Fall (Sep-Nov) $\left({ }^{\circ} \mathrm{C}\right.$ decade $\left.^{-1}\right)$ & $0.60 \pm 0.2$ & $0.67 \pm 0.1$ & $0.68 \pm 0.2$ & $0.56 \pm 0.1$ \\
\hline
\end{tabular}

\section{Results and discussion: observations}

\subsection{Climatology}

The average behaviour of landfast ice at the four sites over the 50+-year record is summarized in Table 3. Ice growth, approximately linear through most of the season, slows after March (Fig. 2). Ice thickness reaches a maximum of $\sim 2-$ $2.3 \mathrm{~m}$ by late May at all sites. Values are consistent with those reported by BC92 and with recent observations of Melling et al. (2015) and Haas and Howell (2015). The standard deviations are nearly uniform (at $\sim 0.2 \mathrm{~m}$ ) across all sites, giving a relatively low coefficient of variation $(\mathrm{CV}$; a measure of relative dispersion defined as the ratio of the standard deviation to the mean) of $\sim 0.1$. The thickest ice is found in Eureka with a 1957-2014 mean of $2.27 \mathrm{~m}$, which is likely due to climatologically lower air temperatures in the fall and winter (Table 3).

Snow depth also appears to grow linearly through the season, peaking in May, but unlike ice thickness the monthly variability is high $(\mathrm{CV} \sim 0.4)$ (Fig. 3). Mean October to May snow depths at Resolute, Eureka and Alert range from $\sim 18$ to $23 \mathrm{~cm}$ compared to only $\sim 8 \mathrm{~cm}$ at Cambridge Bay (Table 3). The rapid buildup of the snow cover due to storms in the fall and early winter, which is evident over the Arctic Ocean multi-year ice cover (Warren et al., 1999; Webster et al., 2014), is not seen in these snow depth records within the CAA. The linear behaviour in snow depth is likely maintained by continuous wind-driven redistribution and densi-

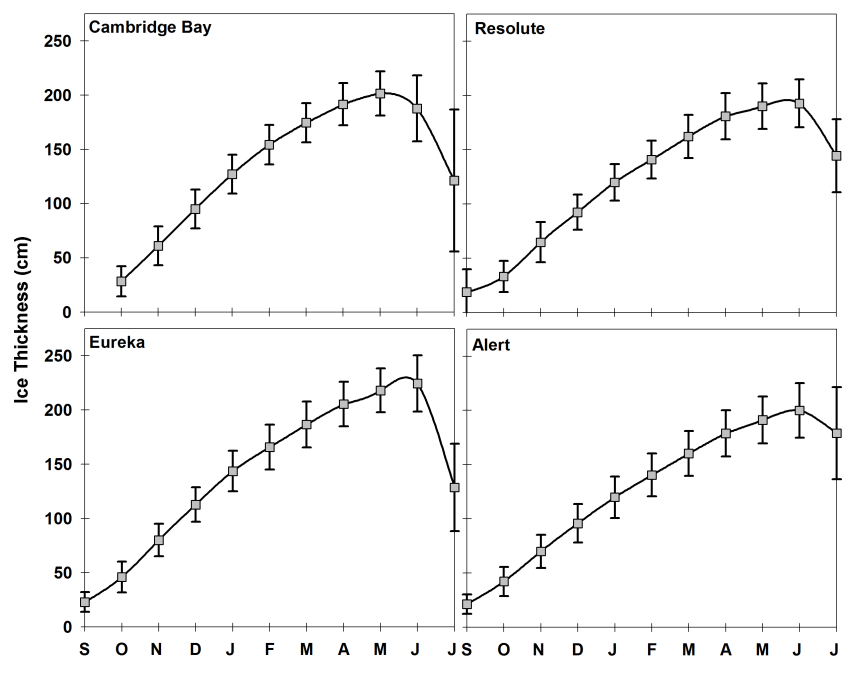

Figure 2. Seasonal cycle of observed mean ice thickness at the four sites (1960-2014).

fication throughout the ice growth season (BC92; Woo and Heron, 1989).

\subsection{Trends}

The time series of maximum ice thickness at Cambridge Bay, Resolute, Eureka and Alert are illustrated in Fig. 4 and summarized in Table 1 . Statistically significant (95\% or greater 


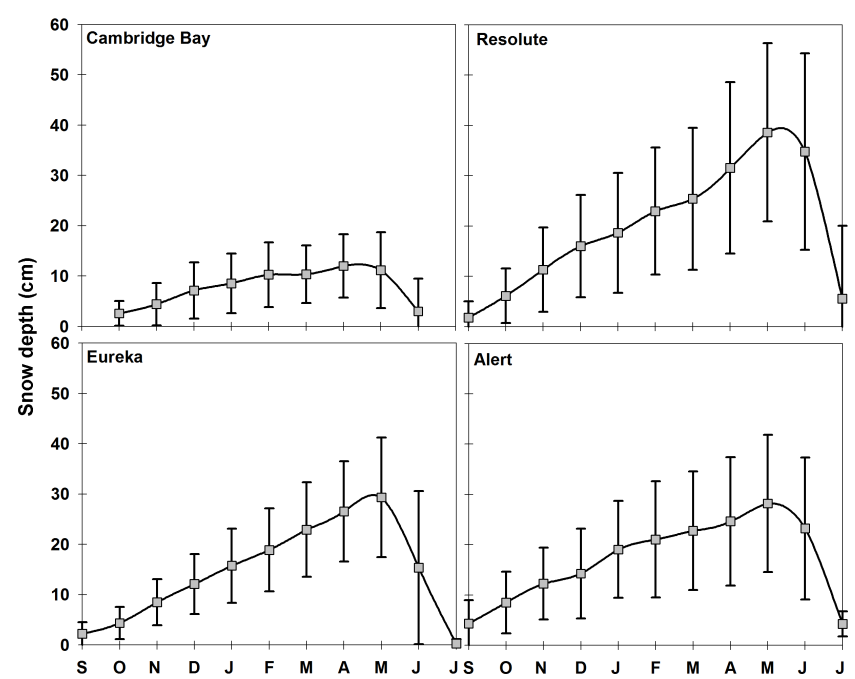

Figure 3. Seasonal cycle of observed mean snow depth at the four sites (1960-2014).

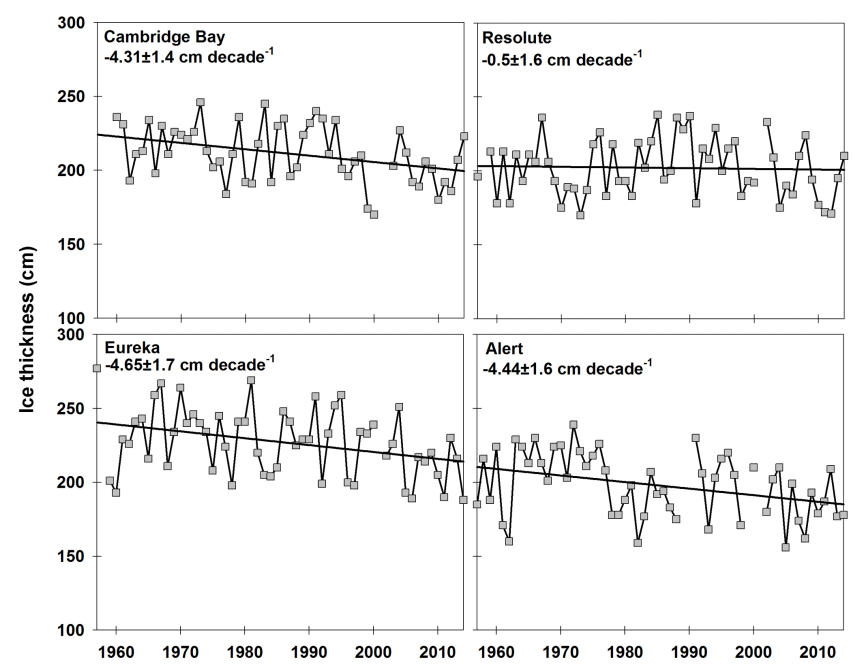

Figure 4. Time series and trend of observed maximum ice thickness at the four sites.

confidence level) negative maximum ice thickness trends are present at Cambridge Bay $\left(-4.31 \pm 1.4 \mathrm{~cm} \mathrm{decade}^{-1}\right)$, Eureka $\quad\left(-4.65 \pm 1.7 \mathrm{~cm} \mathrm{decade}^{-1}\right) \quad$ and Alert $\left(-4.44 \pm 1.6 \mathrm{~cm} \mathrm{decade}^{-1}\right)$ (Table 1). A slight negative trend is present at Resolute but not statistically significant at the $95 \%$ confidence level (Table 1). Over the 50+-year record, the ice thinned by $\sim 0.24-0.26 \mathrm{~m}$ at Cambridge Bay, Eureka and Alert with essentially negligible change at Resolute. These trends in the CAA are similar to trends on the Siberian coast $\left(-3.3 \mathrm{~cm} \mathrm{decade}^{-1}\right.$ ) (Polyakov et al., 2010) but lower in magnitude compared to the Barents Sea $\left(-11 \mathrm{~cm} \mathrm{decade}^{-1}\right)$ (Gerland et al., 2008).

For the shorter record (late 1950s-1989, $~ 30$ years) investigated by $\mathrm{BC} 92$ there was a negative trend at Alert

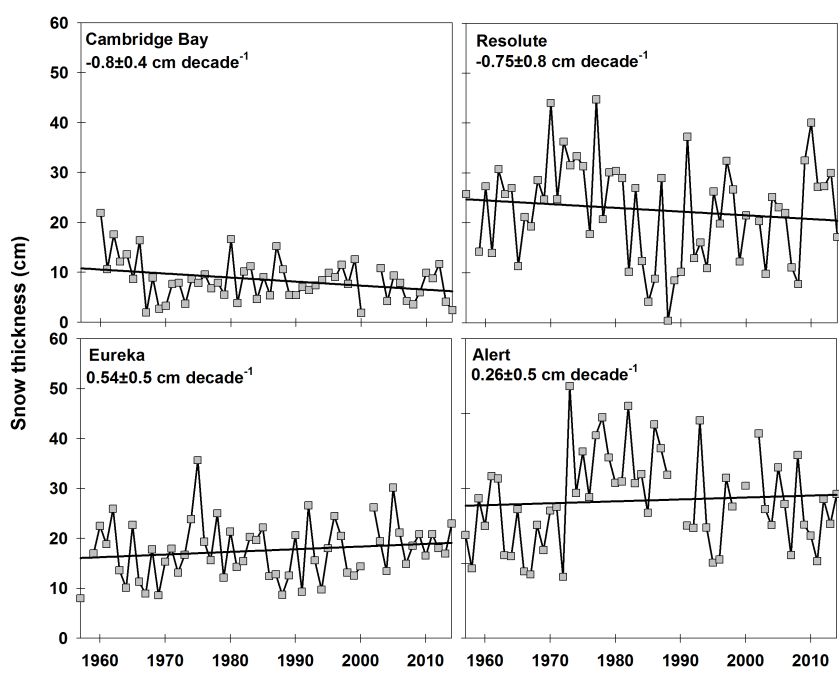

Figure 5. Time series and trend of observed mean snow depth at the four sites from October through May.

$\left(-7.1 \mathrm{~cm} \mathrm{decade}^{-1}\right)$, no evidence of a trend at Eureka and a positive trend at Resolute $\left(10 \mathrm{~cm} \mathrm{decade}^{-1}\right)$, but only the positive trend at Resolute was statistically significant at the $95 \%$ or greater confidence level. Our results from the present $50+$-year record suggest that the negative trend at Alert is robust and the trend at Eureka is now negative and significant. The trend at Resolute is now slightly negative, but it is not statistically significant.

Typically, ice thickness reaches its maximum in late May with trends toward earlier dates of maximum ice thickness present at all sites (significant at Resolute, Eureka and Alert; Table 3). The significant trends are between $-2.0 \pm 0.1$ days decade $^{-1}$ at Eureka and $-6.2 \pm 1.5$ days decade $^{-1}$ at Resolute. At Resolute, the date of maximum ice thickness is now on average more than a month earlier than the early 1960s, although this is not reflected in the trend in ice thickness. Freeze onset at these sites also increases at $\sim 3-6$ days decade $^{-1}$ (Howell et al., 2009) and demonstrates a shortened growth season at Resolute, Eureka and Alert. Together, the trends of ice thickness and their recorded dates suggest a systematic thinning of landfast ice at Cambridge Bay, Eureka and Alert.

\subsection{Ice thickness linkages with snow depth and temperature}

The variability of landfast thickness at these Arctic sites was previously found to be largely driven by interannual variations in snow depth and air temperature (BC92; Flato and Brown, 1996). With the 50+-year record at the four sites, we can examine the corresponding linkages to snow depth and temperature.

For snow depth, the only trend that is statistically significant at the $95 \%$ confidence is Cambridge Bay at 
$-0.8 \pm 0.4 \mathrm{~cm} \mathrm{decade}^{-1}$ (Table 3, Fig. 5). In contrast, BC92 found a significant positive trend at Alert $\left(4 \mathrm{~cm} \mathrm{decade}^{-1}\right)$, a trend of low significance in Eureka and a negative and significant trend at Resolute $\left(-3.3 \mathrm{~cm} \mathrm{decade}^{-1}\right)$. Looking at the detrended correlations $(r)$ between snow depth and ice thickness reveals the strongest correlation at Resolute $(r=-0.71)$ followed by Eureka $(r=-0.66)$, Alert $(r=-0.47)$ and Cambridge Bay $(r=-0.31)$. Figure 6 provides evidence from extreme years of the role of deeper snow inhibiting ice growth compared to thinner snow, but the positive trends in snow thickness are not significant at Resolute, Eureka and Alert. This may in part be due to the single point-wise snow depth and ice thickness measurements made at each point in time, which fail to capture spatial heterogeneity in the snow depth-ice thickness relationship.

With respect to observed temperature, we find significant warming trends in the spring and fall at all sites over the 50+year record (Table 3; Fig. 7). Significant warming is also present at all sites in the summer except Resolute and at all sites during the winter except Eureka (Table 3). Warming is highest during the fall, at $\sim 0.6^{\circ} \mathrm{Cdecade}^{-1}$ at all sites (Table 3 ). The detrended correlation between temperature (winter, spring, summer and fall) and maximum ice thickness is weak at all sites. For example, the strongest detrended correlation between maximum ice thickness and temperature (winter and spring) is found at Cambridge Bay during the winter and spring but is only $\sim 0.4$.

Also of interest is that the observed temperature trends over this period differ considerably from the earlier period investigated in $\mathrm{BC} 92$, in which they reported cooling at all the sites, with a significant cooling trend at Eureka. It was noted that the general cooling over their record coincided with the 1946-1986 cooling trend over much of the eastern Arctic and northwestern Atlantic reported by Jones et al. (1987). This cooling trend halted during the 1980s and the warming, seen in the current and longer record, has resumed (Jones et al., 1999). Arctic land areas have experienced an overall warming of about $\sim 2{ }^{\circ} \mathrm{C}$ since the mid-1960s, with area-wide positive temperature anomalies that show systematic changes since the end of the 20th century, which continued through 2014 (Jeffries and Richter-Menge, 2015). Recently, warming in Canadian Arctic regions was found to be greater than the pan-Arctic trend by up to $0.2^{\circ} \mathrm{Cdecade}^{-1}$ (Tivy et al., 2011).

\section{Results and discussion: models}

\subsection{Climatology}

In order to compare seasonal cycles and trends in landfast ice thickness and snow depth between models and observations, we limit our comparison to models with a reasonable representation of the CAA, i.e. those with an open Parry Channel (i.e. bcc-csm-1-1, bcc-csm-1-1m,
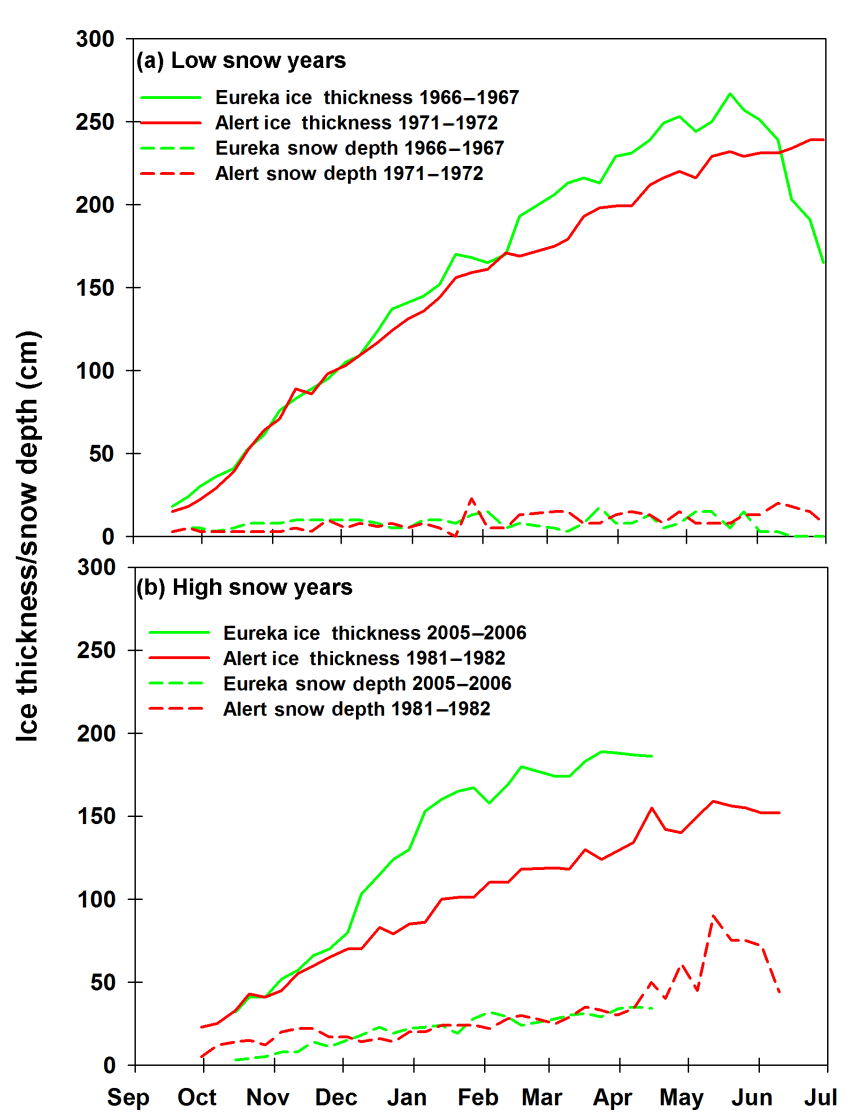

Figure 6. Weekly time series of ice thickness and snow depth at Eureka and Alert for (a) low snow years and (b) high snow years.

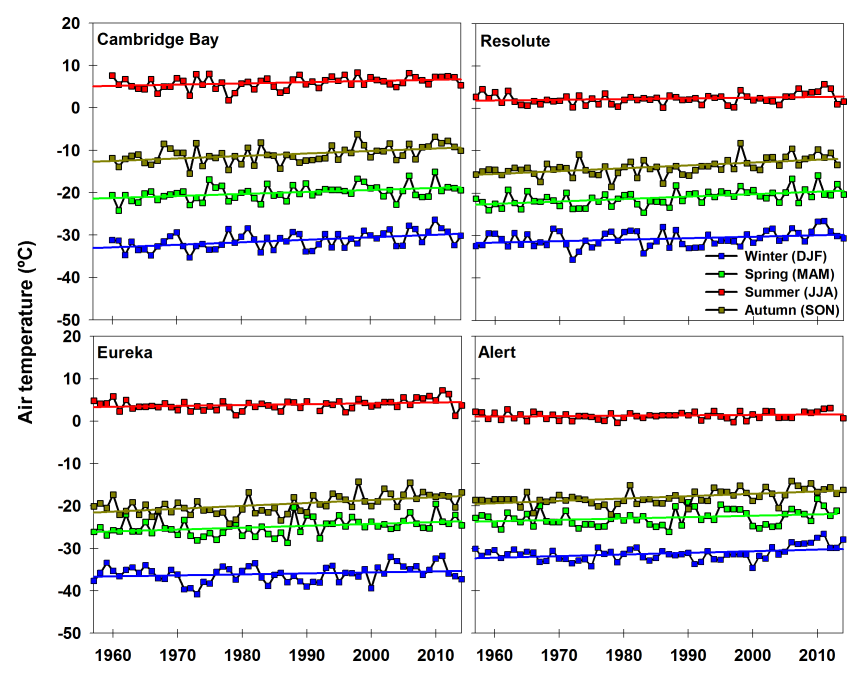

Figure 7. Time series observed mean air temperature by Environment Canada during winter (DFJ), spring, (MAM), summer (JJA) and fall (SON) at the Cambridge Bay, Resolute, Eureka and Alert. 
CNRM-CM5, ACCESS1-0, ACCESS1-3, FIO-ESM, ECEARTH, inmcm4, MIROC5, MPI-ESM-LR, MPI-ESMMR, MRI-CGCM3, CCSM4, NorESM1-M, NorESM1-ME, GFDL-CM3, GFDL-ESM2G, GFL-ESM2M, CESM1-BCG, CESM1-CAM5, CESM-WACCM). In these models, sufficient spatial resolution allows us to find sample points that are almost collocated to in situ observation locations. The sample points were determined by finding the closest ocean grid point where the sea ice is packed for a good portion of the year, but not all year. Grid points with this characteristic therefore share the most important feature of the landfast ice at our observations locations: it is not perennial. Mathematically, we sought sample points where the sea ice concentration is on average above $85 \%$ for more than 1 month but less than 11 months over the 1955-2014 period. The Eureka site is, however, particularly challenging for models because it lies deep in a very narrow channel, which is only resolved by the MPI-ESM-MR in the CMIP5. As a result, for most models, the sample point for Eureka is located on the western shore of Ellesmere Island. This is a consequence of using samples because some models either do not resolve some of the channels in the CAA or have too perennial packed ice cover (e.g. CESM1-CAM5), and then the sample points are further from the observational site than would be desired. We chose to use sample points in our comparison to observations instead of using regional averages for two main reasons. The first reason is that using regional averages would have lumped together different ice dynamics regimes that should not necessarily be expected to compare well to point observations on landfast ice. The second reason is that we are of the opinion that the resolution in many of these models is sufficiently high to warrant such a direct comparison and provides a better benchmark than regional averages for landfast ice modelling in the CAA.

The seasonal cycle (1955-2014) of median ice thickness from CMIP5 (black), ORA-IP models CGLORS, ORAP5.0 and GLORYS2V3 (blue), ECCO-v4 (green) and UR025.4 (red) is shown in Fig. 8. ORA-IP models have been split into three groups based, respectively, on their high, medium and low ice thicknesses at Alert. Ice thickness from CMIP5 is comparable to observations (Fig. 2) at Cambridge Bay and Resolute with maximum ice thickness reaching $200 \mathrm{~cm}$. The ORA-IP models are less consistent. ECCO-v4 tends to have thicker sea ice than observations at Cambridge Bay, Resolute and Eureka but thinner at Alert. CGLORS, ORAP5.0 and GLORYS2V3, however, are comparable to observations at Cambridge Bay, Resolute and Eureka but have extremely thick and perennial ice close to Alert.

The seasonal cycle (1955-2014) of median snow depth from CMIP5 is shown in Fig. 9. CMIP5 models indicate a linear increase similar to observations reaching a maximum of $\sim 20 \mathrm{~cm}$ in April or May. This is lower than the observed maximum at Resolute, Eureka and Alert but is about twice as much as at Cambridge Bay. While the snow depth reaches 0 during the summer at Eureka and Alert in models, the sea ice
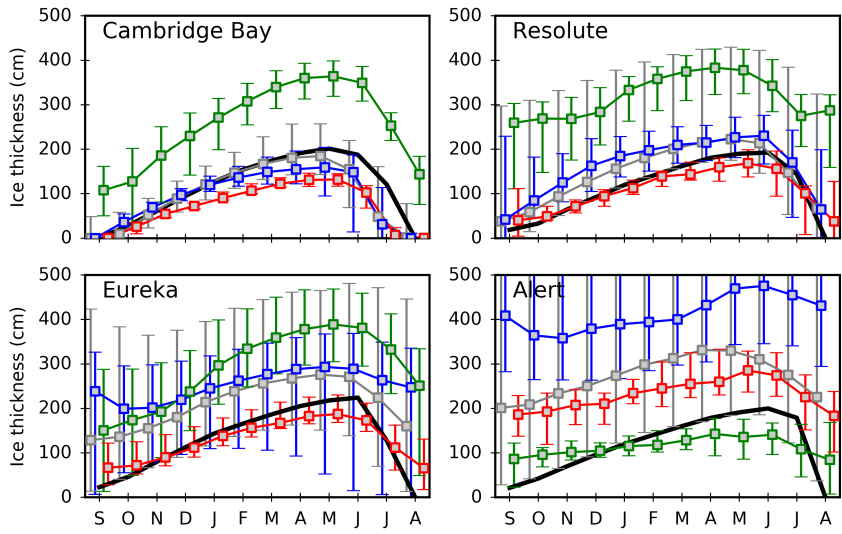

Figure 8. CMIP5 median sea ice thickness seasonal cycle (19552014) at stations (grey). Observations from 2 (black). Median of ORA-IP models CGLORS, ORAP5.0, GLORYS2V3 (blue), ECCO-v4 (green) and UR025.4 (red). Whiskers indicate the 5th and 95th percentiles.
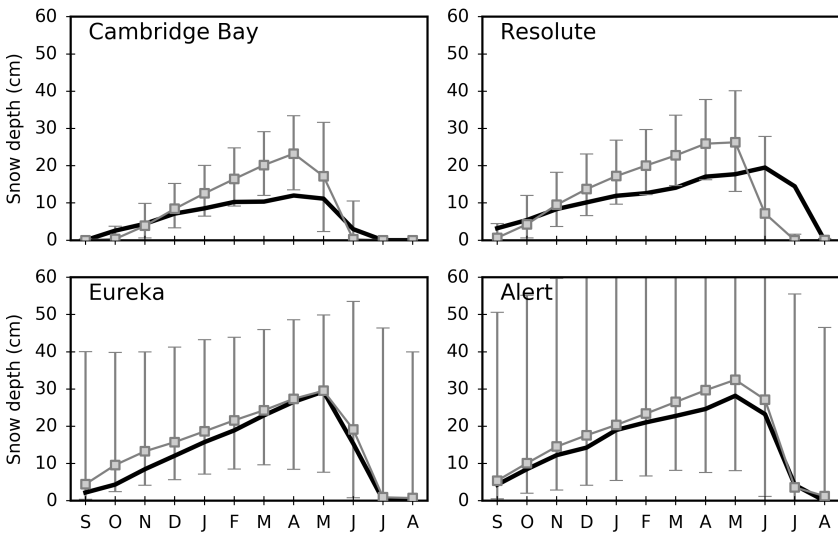

Figure 9. Same as Fig. 8 for snow depth and only for CMIP5 models (grey) and observations (black).

thickness does not (Fig. 8), unlike in observations. This likely reflects the fact that the grid cell thickness in sea ice models with thickness classes a represents the average thickness over these classes. In August the thinner ice classes might have melted but thicker ice classes can still be found, resulting in a substantial average ice thickness over the grid cell. The seasonal cycle over packed ice in these models thus gives a reasonable representation of the seasonal cycle over landfast ice in the CAA, especially in the southern region of the CAA. Overall, this comparison shows how recent improvements in sea ice model resolution allows comparisons with observations that required dynamical downscaling techniques in the previous generation of sea ice models (i.e. Dumas et al., 2005; Sou and Flato, 2009).

Despite relatively high spatial resolution, PIOMAS does not resolve seasonal ice thickness along the coasts and within the very narrow channels within the CAA (not shown). As 


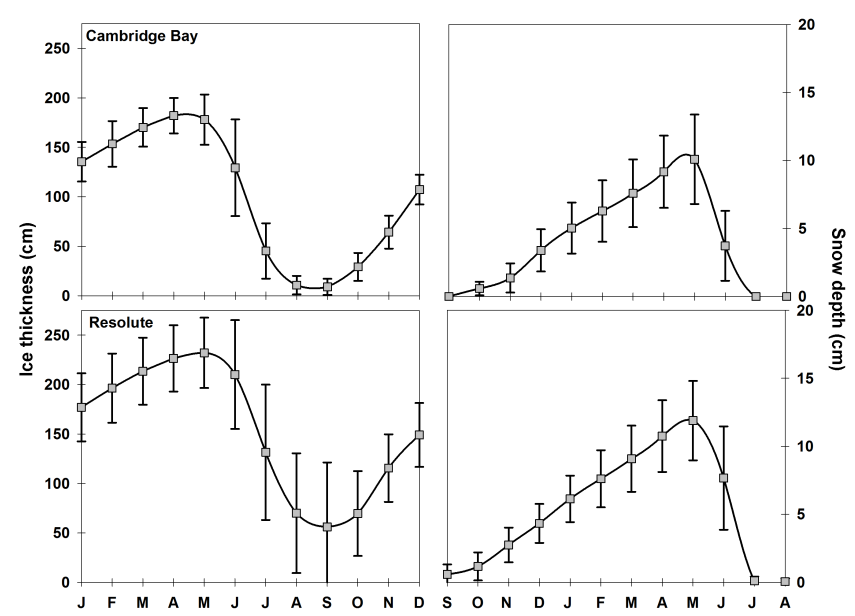

Figure 10. Seasonal cycle of observed mean ice thickness (left) and snow depth (right) from PIOMAS at Cambridge Bay and Resolute (1979-2014).

a result, Cambridge Bay and Resolute Bay sites represent the only long-term monitoring sites within the CAA suitable for comparison since PIOMAS. The monthly time series of PIOMAS ice and snow thickness estimates at Cambridge Bay and Resolute is shown in Fig. 10. The seasonal cycle of ice growth at Cambridge Bay and Resolute is representative compared to observations (Fig. 2) but PIOMAS estimates retain more ice in August and September, particularly at Resolute. Ice growth reaches a maximum in April at Cambridge and in May at Resolute which is 1 month earlier compared to observations. Snow depth follows a linear increase similar to observations (Fig. 3), with good agreement at Cambridge Bay, but considerably underestimates snow depth at Resolute (Fig. 10). Schweiger et al. (2011) performed a detailed comparison of PIOMAS ice thickness values against in situ and Ice, Cloud, and land Elevation Satellite (ICESat) ice thickness observations and found strong correlations. They determined a root mean square error (RMSE) of $\sim 0.76 \mathrm{~m}$ and noted that PIOMAS generally overestimates thinner ice and underestimates thicker ice. At both sites within the CAA, PIOMAS ice thickness data are in reasonably good agreement with in situ observations with RMSEs of $0.29 \mathrm{~cm}$ at Cambridge Bay and $0.68 \mathrm{~cm}$ at Resolute (Fig. 11). The systematic overestimate of thinner ice reported by Schweiger et al. (2011) is more apparent at Resolute than Cambridge Bay (Fig. 11). The higher-latitude regions of the CAA where there is an intricate mix of seasonal first-year ice and multi-year ice is a problem for PIOMAS and thus contributes to the larger discrepancy at Resolute compared to Cambridge Bay.

\subsection{Trends}

The spatial distribution of maximum sea ice thickness trends from ORA-IP and CMIP5 is illustrated in Fig. 12. The CMIP5 model mean exhibits a fairly uniform trend pattern,

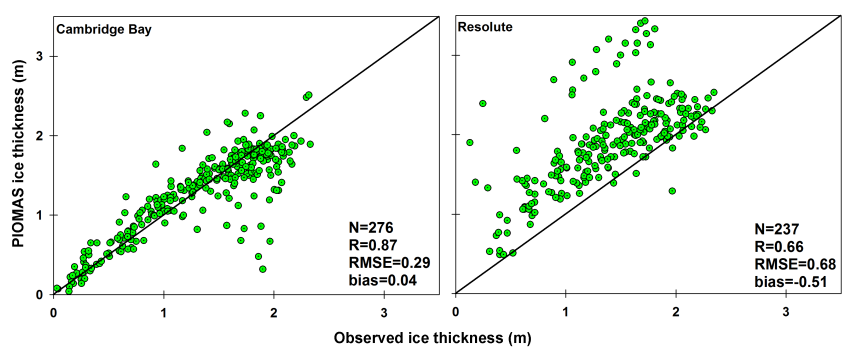

Figure 11. Comparison of PIOMAS ice thickness with ice thickness observations from Environment Canada's ice thickness monitoring sites at Cambridge Bay and Resolute. The data cover the period 1979-2014.

consistent with the different in situ observations (Fig. 4) but with overestimated negative thickness trends. Although for individual models this pattern is far from uniform, the general pattern and magnitude of thickness trends tend to be roughly in accordance with temperature trends (not shown). A similar behaviour is observed in the ORA-IP models, with the notable exception of CGLORS, where positive thickness trends are found almost everywhere (Fig. 12a). This is robust and it appears that the model is not completely equilibrated in the CAA and exhibits large month-to-month adjustments. Model ORAP5.0 also is not completely equilibrated in the region for years 1979-1984. During those years, it exhibits large interannual changes in thickness. For this reason, we are only considering years 1985-2013 for this model.

For PIOMAS, the north-south overestimated trend is also present (not shown) as with CMIP5 and ORA-IP. Looking specifically at trends computed from 1979 to 2014 near the observed sites shows the mean maximum ice thickness linear trend from at Cambridge Bay to be $-13.4+3.4 \mathrm{~cm} \mathrm{decade}^{-1}$, which is almost double the observational trend of $6.2 \pm$ $2.4 \mathrm{~cm}$ decade $^{-1}$. At Resolute, the PIOMAS linear trend is $24.0 \pm 4.1 \mathrm{~cm} \mathrm{decade}^{-1}$, which is considerably stronger than the observational trend of $-4.9 \pm 3.51 \mathrm{~cm} \mathrm{decade}^{-1}$.

\subsection{Ice thickness linkages with snow depth and temperature}

Even though ORA-IP models have unrealistically large thickness trends, the pattern of interannual correlation (detrended) between winter temperatures and thicknesses is roughly consistent across models (Fig. 13). Some ORA-IP models also experience positive correlations (e.g. CGLORS, ORAP5.0, GLORYS2V3 and UR025.4) that are mostly located north of the CAA or within the CAA in regions where multi-year ice is known to be present. It is possible that warmer temperatures are associated with an increased flux of thicker multi-year ice into the CAA, which is known to occur (e.g. Howell et al., 2013), but the driving processes responsible for these positive correlations require more investigation. In CMIP5 models, no model exhibits positive corre- 

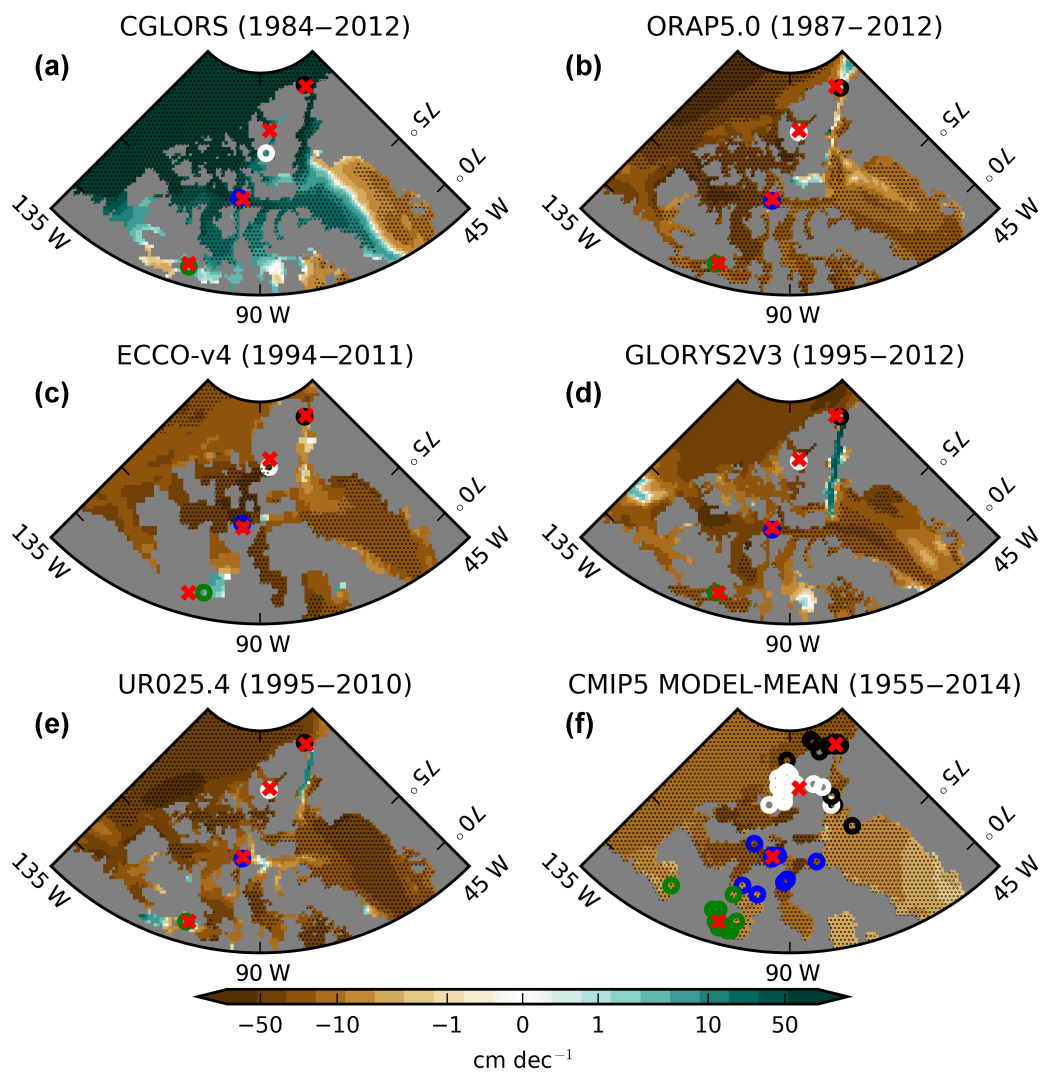

Figure 12. (a-e) Maximum sea ice thickness trends in ORA-IP simulations. (f) Same for CMIP5 model-mean. From south to north, o's indicate Cambridge Bay (green), Resolute (blue), Eureka (white) and Alert (black) and x's indicate the corresponding measurement stations. In (f), one o per model is shown. The stippling indicates $p$ values less than 0.05 , corrected using the false discovery rate method with a global pFDR value less than 0.10 (Wilks, 2006). The colour bar is linear from -10 to $10 \mathrm{~cm} \mathrm{decade}^{-1}$ and symmetric logarithmic beyond these values.

lations with temperature that resembles ORA-IP models over the CAA. Although the time series for the ORA-IP models is short and the positive correlations are only statistically significant at a few grid points in CGLORS and UR025.4, this behaviour is sufficiently problematic to recommend that care should be taken when using these ORA-IP models to study the interannual variability in the Canadian Arctic.

In the CMIP5 models, significant winter snow depth trends are more strongly negative in the north than in the south (Fig. 14). This is in disagreement with point observations presented in the previous sections that showed no significant trends snow depth trends at Alert but negative and significant trends at Cambridge Bay. Although only based on limited point in situ observations, this suggests that over the last decades changes in winter precipitation at Alert must have compensated the increased melting driven by increasing temperatures, a compensation that is clearly not captured in CMIP5 models.

\section{Conclusions}

Over the 50+-year in situ observational record, statistically significant negative trends in maximum (end-of-winter) ice thickness are present at Cambridge Bay, Eureka and Alert. Significant negative trends in the day of maximum ice thickness are also present at Resolute, Eureka and Alert. Together, these trends suggest thinning of landfast ice in the CAA, where little evidence was found in the shorter record analysed in an earlier study (BC92). The interannual variability of air temperature is only weakly correlated to maximum ice thickness (i.e. maximum correlation is $\sim 0.4$ ). Snow thickness plays the dominant role in controlling maximum ice thickness variability given the high correlations at Resolute and Eureka and reasonably high correlations at Alert and Cambridge Bay.

Comparison of CMIP5, ORA-IP and PIOMAS simulations with observations indicate a reasonable representation of the landfast ice thickness monthly climatology within the CAA. This is particularly apparent when seasonal first-year ice dominates the icescape (i.e. Cambridge Bay). Despite im- 

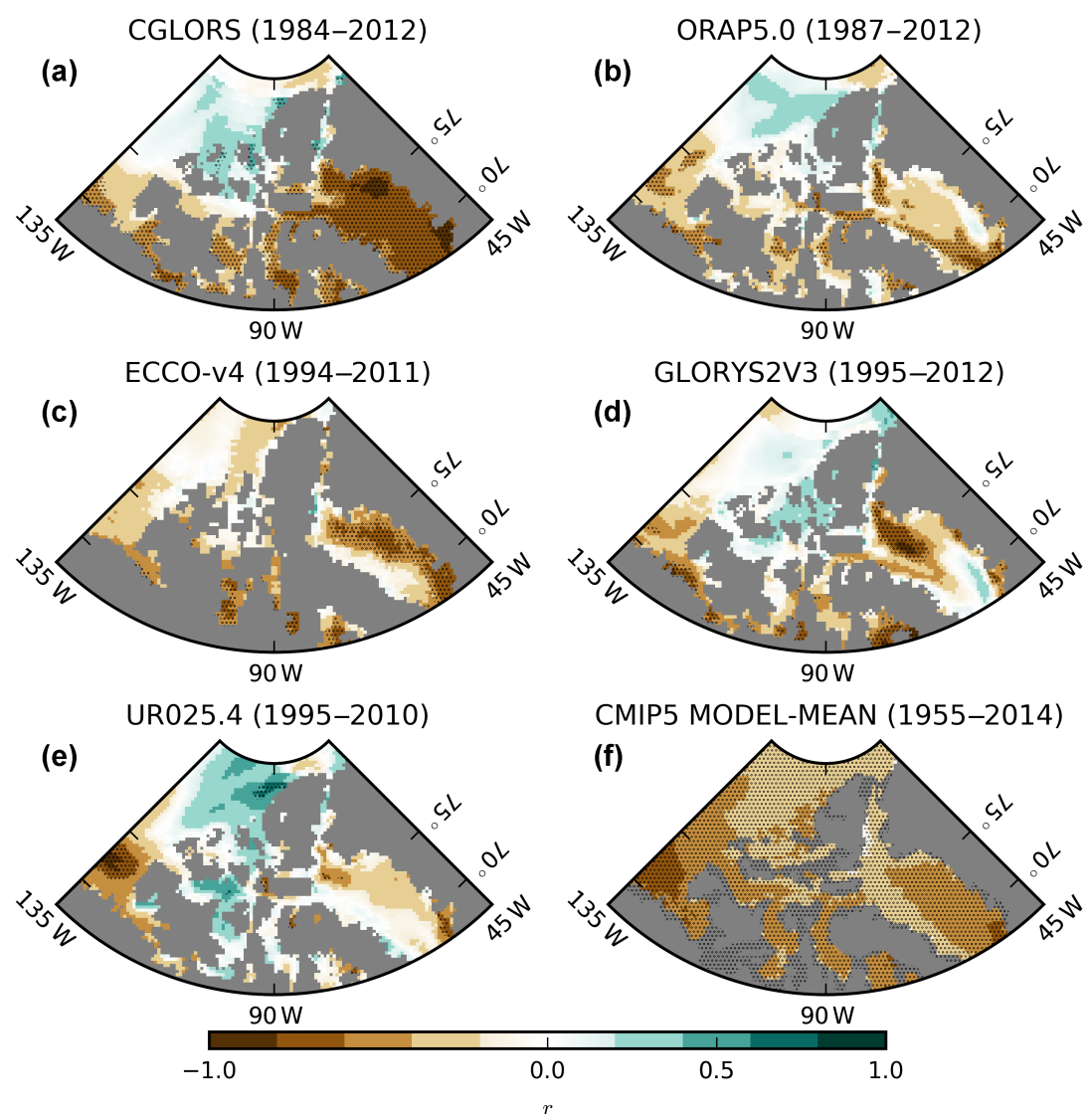

Figure 13. (a-e) Pearson correlation of detrended maximum sea ice thickness in ORA-IP with detrended ONDJFMAM ERA-INTERIM $2 \mathrm{~m}$ temperature. (f) Same but for CMIP5 MODEL-MEAN. The stippling indicates $p$ values less than 0.05 , corrected using the false discovery rate method with a global pFDR value less than 0.10 (Wilks, 2006).

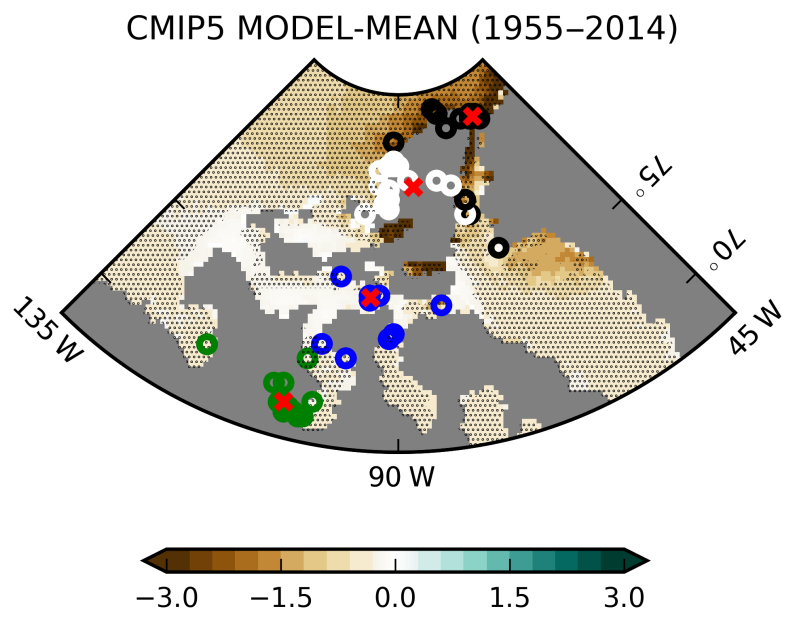

Figure 14. Same as Fig. 12f but for snow depth trends (ONDJFMAM).

provements in spatial resolution, mixed ice types (i.e. seasonal and multi-year) present at the sub-grid cell resolution are likely problems for model estimates within the CAA.
The overall thickness of ice within the CAA in the current generation of models is too high. As a result, trends are unrealistic and far exceed observations (by upwards of $-50 \mathrm{~cm} \mathrm{decade}^{-1}$ ) in part because the initial ice thickness is too large. The problem is particularly acute in the ORA-IP models where large and unrealistic interannual changes in thickness suggest that the models are not fully equilibrated.

While the impact of the snow cover on ice thickness is well known, the significant correlations at Resolute, Eureka and Alert suggest that the higher sensitivity to changes in snow depth could potentially mask the warming signal on both fast and offshore ice. Thus, even in this limited data set, we can see the dominant role played by snow depth in determining the interannual variability of the maximum landfast ice thickness. This again highlights that the primary factor is the amount and timing of snow accumulation rather than air temperature. However, it is worth noting that few of the current generation models show coherent relationships between ice thickness, snow depth and temperature over the longerterm record. 


\section{Appendix A:}

The Monte Carlo simulation used to combine trends and Pearson correlations is applied at each grid point independently. Models that have a land mask at a grid point are discarded before starting the procedure.

A noise model is created to ensure that internal variability is comparable for models with different ensemble sizes, following Swart et al. (2015) and Laliberté et al. (2016). To generate the noise model, we discard models that have fewer than two realizations. From the remaining models, we pick one and then one of its realizations. We then record to the noise model the difference of this realization's trend from the mean trend of the model's realizations, multiplied by $(n /(n-1))^{1 / 2}$, with $n$ being the number of realizations, to account for the fact that some models have such a small number of realizations that it cannot completely account for the internal variability. We repeat this procedure 1000 times and compute the variance $\sigma_{\mathrm{n}}$ of the noise model.
We then pick a model from which we select 1000 realizations, allowing repetitions. For each one of these realizations, we select a random value from its trend $t$ distribution. If the inter-realization trend variance $\sigma_{\mathrm{m}}$ is smaller than the variance of the noise model $\sigma_{\mathrm{n}}$, we then draw a random value from the noise model, multiply it by $\left(1-\sigma_{\mathrm{m}} / \sigma_{\mathrm{n}}\right)^{1 / 2}$ and add it to the random value from the trend $t$ distribution.

We repeat this procedure with the remaining models. We then average the 1000 values across models, creating a distribution for the multi-model mean trend with 1000 values. The mean of this distribution gives our multi-model mean and its two-sided $p$ value is given by twice its survival function or cumulative distribution function at 0 , whichever is smallest.

The Pearson correlations are analysed in the same way except that a Fisher transform (obtained by the hyperbolic arc tangent of the correlation) is applied first and random values are drawn from a normal distribution (instead of the $t$ distribution) with variance $1 /(T-3)$, with $T$ the number of years used for the correlation. The multi-model mean Pearson correlation is then given by the inverse Fisher transform (obtained by the hyperbolic tangent of the mean) of the distribution mean. 


\section{The Supplement related to this article is available online at doi:10.5194/tc-10-1463-2016-supplement.}

Author contributions. Stephen E. L. Howell, Frédéric Laliberté and Ron Kwok designed the study, performed the analysis and wrote the manuscript with input from Chris Derksen and Joshua King.

Acknowledgements. The authors with to thank all the individuals responsible for collecting landfast ice and snow thickness measurements in the Canadian Arctic over the past 50+ years.

Edited by: L. Kaleschke

Reviewed by: D. Bailey and one anonymous referee

\section{References}

Alt, B., Wilson, K., and Carrieres, T.: A case study of old ice import and export through Peary and Sverdrup channels in the Canadian Arctic Archipelago: 1998-2004, Ann. Glaciol., 44, 329338, doi:10.3189/172756406781811321, 2006.

Balmaseda, M. A., Hernandez, F., Storto, A., et al.: The Ocean Reanalyses Intercomparison Project (ORAIP), Journal of Operational Oceanography, 8, s80-s97, doi:10.1080/1755876X.2015.1022329, 2015.

Brown, R. and Cote, P.: Interannual variability of landfast ice thickness in the Canadian high arctic, 1950-89, Arctic, 45, 273-284, 1992. Chevallier, M., Smith, G. C., Dupont, F., Lemieux, J.-F., Forget, G., Fujii, Y., Hernandez, F., Msadek, R., Peterson, K. A., Storto, A., Toyoda, T., Valdivieso, M., Vernieres, G., Zuo, H., Balmaseda, M., Chang, Y.-S., Ferry, N., Garric, G., Haines, K., Keeley, S., Kovach, R. M., Kuragano, T., Masina, S., Tang, Y., Tsujino, H., and Wang, X.: Intercomparison of the Arctic sea ice cover in global ocean-sea ice reanalyses from the ORA-IP project, Clim. Dynam., 1-30, doi:10.1007/s00382-016-2985-y, 2016.

Dee, D. P., Uppala, S. M., Simmons, A. J., et al.: The ERAInterim reanalysis: configuration and performance of the data assimilation system, Q. J. Roy. Meteor. Soc., 137, 553-597, doi:10.1002/qj.828, 2011.

Dumas, J. A., Flato, G. M., and Brown, R. D.: Future projections of landfast ice thickness and duration in the Canadian Arctic, J. Climate, 19, 5175-5189, 2006.

Druckenmiller, M. L., Eicken, H., Johnson, M. A., Pringle, D. J., and Williams, C. C.: Toward an integrated coastal sea-ice observatory: System components and a case study at Barrow, Alaska, Cold Reg. Sci. Technol., 56, 61-72, 2009.

Flato, G. M. and Brown, R. D.: Variability and climate sensitivity of landfast Arctic sea ice, J. Geophys. Res., 101, 25767-25777, 1996.

Forget, G., Campin, J.-M., Heimbach, P., Hill, C. N., Ponte, R. M., and Wunsch, C.: ECCO version 4: an integrated framework for non-linear inverse modeling and global ocean state estimation, Geosci. Model Dev., 8, 3071-3104, doi:10.5194/gmd-8-30712015, 2015.
Gerland, S., Renner, A. H. H., Godtliebsen, F., Divine, D., and Loyning, T. B.: Decrease of sea ice thickness at Hopen, Barents Sea, during 1966-2007, Geophys. Res. Lett., 35, L06501, doi:10.1029/2007GL032716, 2008.

Gough, W., Gagnon, A. S., and Lau, H. P.: Interannual variability of Hudson Bay Ice Thickness, Polar Geography, 28, 222-238, 2004.

Haas, C. and Howell, S. E. L.: Ice thickness in the Northwest Passage, Geophys. Res. Lett., 42, 7673-7680, doi:10.1002/2015GL065704, 2015.

Haines, K., Valdivieso, M., Zuo, H., and Stepanov, V. N.: Transports and budgets in a $1 / 4^{\circ}$ global ocean reanalysis 1989-2010, Ocean Sci., 8, 333-344, doi:10.5194/os-8-333-2012, 2012.

Howell, S. E. L., Duguay, C. R., and Markus, T.: Sea ice conditions and melt season duration variability within the Canadian Arctic Archipelago: 1979-2008, Geophys. Res. Lett., 36, L10502, doi:10.1029/2009GL037681, 2009.

Howell, S. E. L., Wohlleben, T., Dabboor, M., Derksen, C., Komarov, A., and Pizzolato, L.: Recent changes in the exchange of sea ice between the Arctic Ocean and the Canadian Arctic Archipelago, J. Geophys. Res.-Oceans, 118, 3595-3607, doi:10.1002/jgrc.20265, 2013.

Jeffers, S., Agnew, T., Alt, B., De Abreu, R., and McCourt, S.: Investigating the anomalous sea ice conditions in the Canadian High Arctic (Queen Elizabeth Islands) during the summer of 1998, Ann. Glaciol., 33, 507-612, 2001.

Jeffries, M. O. and Richter-Menge, J. (Eds.): The Arctic [in State of the Climate in 2014], B. Am. Meteor. Soc., 96, ES1-ES32, doi:10.1002/qj.2527, 2015.

Jones, P. D., Wigley, T. M. L., Folland, C. K., and Parker, D. E.: Spatial patterns in recent worldwide temperature trends, Climate Monitor, 16, 175-185, 1987.

Jones, P. D., New, M., Parker, D. E., Martin, S., and Rigor, I. G.: Surface air temperature and its changes over the past 150 years, Rev. Geophys., 37, 173-200, 1999.

Kwok, R. and Rothrock, D. A.: Decline in Arctic sea ice thickness from submarine and ICESat records: 1958-2008, Geophys. Res. Lett., 36, L15501, doi:10.1029/2009GL039035, 2009.

Laliberté, F., Howell, S. E. L., and Kushner, P. J.: Regional variability of a projected sea ice-free Arctic during the summer months, Geophys. Res. Lett., 43, 256-263, doi:10.1002/2015GL066855, 2016.

Laxon S. W., Giles, K. A., Ridout, A. L., Wingham, D. J., Willatt, R., Cullen, R., Kwok, R., Schweiger, A., Zhang, J., Haas, C., Hendricks, S., Krishfield, R., Kurtz, N., Farrell, S., and Davidson, M.: CryoSat-2 estimates of Arctic sea ice thickness and volume, Geophys. Res. Lett., 40, 732-737, doi:10.1002/grl.50193, 2013.

Mahoney, A., Eicken, H., and Shapiro, L.: How fast is landfast sea ice? A study of the attachment and detachment of nearshore ice at Barrow, Alaska, Cold Reg. Sci. Technol., 47, 233-255, 2007.

Mahoney, A. R., Eicken, H., Gaylord, A. G., and Gens, R.: Landfast sea ice extent in the Chukchi and Beaufort seas: The annual cycle and decadal variability, Cold Reg. Sci. Technol., 103, 41-56, doi:10.1016/j.coldregions.2014.03.003, 2014.

Masina, S., Storto, A., Ferry, N., Valdivieso, M., Haines, K., Balmaseda, M., Zuo, H., Drevillon, M., and Parent, L.: An ensemble of eddy-permitting global ocean reanalyses from the MyOcean project, Clim. Dynam., 1-29, doi:10.1007/s00382-015-2728-5, 2015. 
Melling, H.: Sea ice of the northern Canadian Arctic Archipelago, J. Geophys. Res., 107, 3181, doi:10.1029/2001JC001102, 2002.

Melling, H., Haas, C., and Brossier, E.: Invisible polynyas: Modulation of fast ice thickness by ocean heat flux on the Canadian polar shelf, J. Geophys. Res.-Oceans, 120, 777-795, doi:10.1002/2014JC010404, 2015.

Polyakov, I. V., Timokhov, L. A., Alexeev, V. A., Bacon, S., Dmitrenko, I. A., Fortier, L., Frolov, I. E., Gascard, J.-C., Hansen, E., Ivanov, V. V., Laxon, S., Mauritzen, C., Perovich, D., Shimada, K., Simmons, H. L., Sokolov, V. T., Steele, M., and Toole, J.: Arctic Ocean Warming Contributes to Reduced Polar Ice Cap, J. Phys. Oceanogr., 40, 2743-2756, 2010.

Schweiger, A., Lindsay, R., Zhang, J., Steele, M., Stern, H., and Kwok, R.: Uncertainty in modeled Arctic sea ice volume, J. Geophys. Res., 116, C00D06, doi:10.1029/2011JC007084, 2011.

Serson, H. V.: Investigations of a plug of multiyear old sea icein the mouth of Nansen Sound, Department of National Defence, Canada. Defence Research Establishment Ottawa (DREO), Ontario, Canada, Technical Note 72-6, 1972.

Serson, H. V.: Sverdrup Channel, Department of National Defence, Defence Research Board, Defence Research Establishment Ottawa (DREO), Ontario, Canada, Technical Note 74-10, 31 pp., 1974.

Sou, T. and Flato, G.: Sea ice in the Canadian Arctic Archipelago: Modeling the past (1950-2004) and the future (2041-60), J. Climate, 22, 2181-2198, doi:10.1175/2008JCLI2335.1, 2009.

Storto, A., Dobricic, S., Masina, S., and Di Pietro, D.: Assimilating along-track altimetric observations through local hydrostatic adjustments in a global ocean reanalysis system, Mon. Weather Rev., 139, 738-754, 2011.

Stroeve, J. C., Serreze, M. C., Holland, M. M., Kay, J. E., Maslanik, J., and Barrett, A. P.: The Arctic's rapidly shrinking sea ice cover: A research synthesis, Climatic Change, 110, 1005-1027, 2012.

Swart, N. C., Fyfe, J. C., Hawkins, E., Kay, J. E., and Jahn, A.: Influence of internal variability on Arctic sea-ice trends, Nature Climate Change, 5, 86-89, doi:10.1038/nclimate2483, 2015.

Taylor, K. E., Stouffer, R. J., and Meehl, G. A.: An overview of CMIP5 and the experiment design, B. Am. Meteorol. Soc., 93, 485-498, doi:10.1175/BAMS-D-11-00094.1, 2012.
Tivy, A., Howell, S. E. L., Alt, B., McCourt, S., Chagnon, R., Crocker, G., Carrieres, T., and Yackel, J. J.: Trends and variability in summer sea ice cover in the Canadian Arctic based on the Canadian Ice Service Digital Archive, 1960-2008 and 1968-2008, J. Geophys. Res., 116, C03007, doi:10.1029/2009JC005855, 2011.

Vincent, L. A., Wang, X. L., Milewska, E. J., Wan, H., Yang, F., and Swail, V.: A second generation of homogenized Canadian monthly surface air temperature for climate trend analysis, J. Geophys. Res., 117, D18110, doi:10.1029/2012JD017859, 2012.

Warren, S. G., Rigor, I. G., Untersteiner, N., Radionov, V. F., Bryazgin, N. N., Aleksandrov, Y. I., and Colony, R.: Snow depth on Arctic sea ice, J. Climate, 12, 1814-1829, 1999.

Webster, M. A., Rigor, I. G., Nghiem, S. V., Kurtz, N. T., Farrell, S. L., Perovich, D. K., and Sturm, M.: Interdecadal changes in snow depth on Arctic sea ice, J. Geophys. Res. Oceans, 119, 53955406, doi:10.1002/2014JC009985, 2014.

Wilks, D. S.: On "field significance" and the false discovery rate, J. Appl. Meteorol. Clim., 45, 1181-1189, doi:10.1175/JAM2404.1, 2006.

Woo, M.-K. and Heron, R.: Freeze-up and break-up of ice cover on small arctic lakes, in: Northern lakes and rivers, edited by: Mackay, W. C., Boreal Institute for Northern Studies, Edmonton, 56-62, 1989.

World Meteorological Organization: WMO sea-ice nomenclature, Terminology, codes and illustrated glossary, Geneva Secretariat of the World Meteorological Organization, WMO/OMM.BMO No. 259, 145 pp., 1970.

Yu, Y., Stern, H., Fowler, C., Fetterer, F., and Maslanik, J.: Interannual Variability of Arctic Landfast Ice between 1976 and 2007 J. Climate, 27, 227-243, doi:10.1175/JCLI-D-13-00178.1, 2014

Zhang, J. L. and Rothrock, D. A.: Modeling global sea ice with a thickness and enthalpy distribution model in generalized curvilinear coordinates, Mon. Weather Rev., 131, 845-861, 2003.

Zuo, H., Balmaseda, M. A., and Mogensen, K.: The new eddypermitting ORAP5 ocean reanalysis: description, evaluation and uncertainties in climate signals, Clim. Dynam., 1-21, doi:10.1007/s00382-015-2675-1, online first, 2015. 